\title{
Research
}

\section{Verbal and non-verbal behaviour and patient perception of communication in primary care:}

\author{
an observational study
}

\begin{abstract}
Background

Few studies have assessed the importance of a broad range of verbal and non-verbal consultation behaviours.
\end{abstract}

Aim

To explore the relationship of observer ratings of behaviours of videotaped consultations with patients' perceptions.

\section{Design and setting}

Observational study in general practices close

to Southampton, Southern England.

\section{Method}

Verbal and non-verbal behaviour was rated by independent observers blind to outcome. Patients competed the Medical Interview Satisfaction Scale (MISS; primary outcome) and questionnaires addressing other communication domains.

\section{Results}

In total, 275/360 consultations from 25 GPs had useable videotapes. Higher MISS scores were associated with slight forward lean lan 0.02 increase for each degree of lean, $95 \%$ confidence interval $[\mathrm{Cl}]=0.002$ to 0.03 ), the number of gestures $(0.08,95 \% \mathrm{Cl}=0.01$ to 0.15$)$ 'back-channelling' (for example, saying ' $\mathrm{mmm}$ ') $(0.11,95 \% \mathrm{Cl}=0.02$ to 0.2$)$, and social talk (0.29, $95 \% \mathrm{Cl}=0.4$ to 0.54 ). Starting the consultation with professional coolness ('aloof') was helpful and optimism unhelpful. Finishing with nonverbal 'cut-offs' (for example, looking away), being professionally cool ('aloof'), or patronising. ('infantilising') resulted in poorer ratings. Physical contact was also important, but not traditional verbal communication.

\section{Conclusion}

These exploratory results require confirmation, but suggest that patients may be responding to several non-verbal behaviours and non-specific verbal behaviours, such as social talk and back-channelling, more than traditional verbal behaviours. A changing consultation dynamic may also help, from professional 'coolness' at the beginning of the consultation to becoming warmer and avoiding non-verbal cut-offs at the end.

\section{Keywords}

communication; consultation; general practice: non-verbal communication.

\section{INTRODUCTION}

The patient-centred consultation model is widely advocated, ${ }^{1,2}$ although implementation is possibly limited, ${ }^{3-5}$ and poor communication results in complaints and lawsuits. ${ }^{6}$ Communication skills training is also probably very efficient given the long-lasting effects of training. . $^{7-10}$

A Cochrane Review of trials to modify patient-centredness documented mixed effects on satisfaction and small effects on health status..11 However, for satisfaction, none of the studies addressed non-verbal skills, and nearly all were intensive ('brief' training was up to 10 hours). ${ }^{11}$ Most models of patient-centred behaviour refer to traditional verbal skills, but a review of 22 observational studies suggested that other important factors were courtesy, empathy, positive reinforcement, reassurance and support, psychosocial talk, friendliness, humour, explanations, summarising and clarification, a direct body orientation, symmetrical legs and arms, forward lead, nodding, and gaze. ${ }^{12}$ An observational study identified important domains of patients' perceptions - a communication and partnership approach, interest in the patient's life, health promotion, a positive approach, and a personal relationship each of which strongly predicts different outcomes. 13,14 However, what mixture of verbal and non-verbal elements of doctor

P Little, BA, MSc, FMedSci, FRCGP, MRCP, MD, professor of primary care research; J Kelly. BSc, MSc, study manager; $\boldsymbol{H}$ Everitt, BSc, MSc PhD, MRCGP, associate professor; S Gashi, BM, GPVTS1, medical student; Primary Care Group, Primary Care and Population Sciences Unit, Faculty of Medicine, University of Southampton, Southampton. P White, MSc, MBBS, GP Nightingale Surgery, Romsey. A Bikker, MSc research associate, SW Mercer, BSc, MSc, PhD, FRCGP, professor of primary care research, General Practice \& Primary Care, Institute of Health and Wellbeing, University of Glasgow, Glasgow. behaviour determines patients' perceptions is less clear.

The previous literature also has significant limitations, great variability in what is rated ffew include even the limited variables assessed by Beck et all, ${ }^{12}$ and outcomes. In one review of trials, meta-analysis was not possible due to the heterogeneity of interventions and outcomes, ${ }^{15}$ and in the Cochrane Review updated in 2012 heterogeneity was also moderately high. ${ }^{11}$

This study aimed to explore which aspects of GPs' non-verbal and verbal communication are likely to be most important in determining patients satisfaction and perceptions of personcentred communication in the consultation.

\section{METHOD}

Unselected GP consultations for consecutive patients were videotaped and verbal and non-verbal behaviour was rated by independent observers blind to outcome. Patients completed ratings postconsultation questionnaires using the Medical Interview Satisfaction Scale (MISS) and other scales measuring the patientcentredness of the consultation.

\section{Participants}

Participants were adult patients, or children attending with their parents, for a new or ongoing problem, that is, not those attending

\section{Address for correspondence}

Paul Little, Primary Care Group, Primary Care and Population Sciences Unit, Faculty of Medicine, University of Southampton, Aldermoor Health Centre, Southampton, S016 5ST, UK.

E-mail: p.littledsoton.ac.uk

Submitted: 23 August 2014; Editor's response: 6 October 2014; final acceptance: 13 November 2014. (c)British Journal of General Practice

This is the full-length article (published online 26 May 2015) or an abridged version published in print. Cite this article as: Br J Gen Pract 2015; DOI: 10.3399/bjgp15X685249 


\section{How this fits in}

Communication is central to every consultation and although a range of key elements have been advocated, few previous studies have assessed the impact of a wide range of verbal and non-verbal behaviours. This study suggests that clinicians may need to pay at least as much attention to non-verbal behaviours and non-specific verbal behaviours, such as social talk and back-channelling, as traditional verbal behaviours. They should avoid optimism but maintain professional 'coolness' at the beginning of the consultation, and end the consultation with warmth, avoiding non-verbal cut-offs.

simply for a repeat prescription. There were no exclusions apart from the inability to consent or complete questionnaires; for example, those experiencing severe distress, dementia, very severe depression, or who were very severely unwell.

\section{Recruitment}

Consecutive patients were recruited by $25 \mathrm{GPs}$ in general practices close to Southampton in Southern England. The GPs in turn were recruited by the local postgraduate coordinator close to the Southampton postgraduate centre. GPs were asked to recruit up to 15 consecutive patients each.

\section{Rating of videotapes}

Doctors were videotaped with the video camera pointed towards the doctor. Prior findings demonstrated that short consultation 'slices' correlate well to total ratings; this was confirmed for most items, but where poor correlations were observed (for example, for Roter items Roter Interaction Analysis System - such as social talk), the whole consultation was used. Thus, unless specified, the first and last minutes of the consultation were rated. The middle of the consultation was not chosen to avoid examinations performed away from the camera. Ratings were blind to the questionnaire responses by a research assistant or member of the research team using a battery of assessments. Particular assessments were chosen based on previous significant findings. Further details of rating of videotapes and descriptive data for key variables are available from the authors.

\section{Patient questionnaires}

A similar methodology was used to the previous study: $:^{14}$ a post-consultation questionnaire explored the patient's perception of communication. Questionnaires were completed by participants with help from parents as appropriate, particularly for very young children, either immediately after the consultation or, more commonly, at home and then posted back.

Primary outcome. The Medical Interview Satisfaction Scale (MISS) ${ }^{16}$ was chosen since its domains predominantly reflect communication and the doctorpatient relationship (distress-relief; communication-comfort; rapport; and compliance-intent). Patients agree or disagree on a 7-point Likert scale lvery strongly agree to very strongly disagree) with items about how they rated the consultation.

Secondary outcomes. Similar 7-point Likert scales were also completed for several domains of patients' perceptions of communication previously validated: ${ }^{14}$

- communication and partnership;

- a 'personal' relationship;

- health promotion;

- a 'positive' approach - being definite about the problem and when it would settle; and

- interest in the effect on life.

The questionnaire also contained sociodemographic details, the short state anxiety questionnaire, ${ }^{17}$ the Whitley Index, the number of medical problems, current medication, enablement, ${ }^{18}$ symptom burden (Measure Yourself Medical Outcome Profile), ${ }^{19}$ whether seeing their usual doctor, the complaint (based on British National Formulary chapters), and whether or not this was ongoing.

\section{Sample size}

The sample size was calculated using an $\alpha$ of 0.01 and $\beta$ of 0.2 using the NQuery sample size programme version 3 . It was estimated that to detect a correlation of 0.25 between patient perception of communication and verbal or non-verbal communication rated in the consultation required 183 patients, or 229 allowing for $20 \%$ incomplete outcomes. Therefore 0.25 was chosen to allow for some margin of error: a correlation of 0.29 was observed between verbal behaviour and satisfaction in a similar previous UK study. ${ }^{20}$ 
Table 1. Variables (scored from videotapes) significantly associated with the mean item score of the MISS questionnaire (rated by patients after the consultation; each item scored 1-7)

\begin{tabular}{|c|c|c|c|c|}
\hline Predictor variables ${ }^{\mathrm{a}}$ & $\begin{array}{l}\text { Univariate beta } \\
\text { coefficient } \\
\text { (95\% Cl) }\end{array}$ & $P$-value & $\begin{array}{c}\text { Multivariate } \\
\text { beta coefficient } \\
(95 \% \mathrm{Cl})\end{array}$ & $P$-value \\
\hline $\begin{array}{l}\text { Non-verbal } \\
\text { Number of gestures } \\
\text { (beginning consultation) }\end{array}$ & $\begin{array}{c}0.11 \\
\text { (0.02 to } 0.19)\end{array}$ & 0.018 & $\begin{array}{c}0.08 \\
(0.001 \text { to } 0.15)\end{array}$ & 0.046 \\
\hline $\begin{array}{l}\text { Degrees of lean towards the } \\
\text { patient (beginning consultation) }\end{array}$ & $\begin{array}{c}0.014 \\
(-0.001 \text { to } 0.029)\end{array}$ & 0.067 & $\begin{array}{c}0.018 \\
(0.002 \text { to } 0.03)\end{array}$ & 0.025 \\
\hline $\begin{array}{l}\text { Verbal } \\
\text { Back-channel prompts } \\
\text { (beginning consultation) }\end{array}$ & $\begin{array}{c}0.10 \\
(-0.02 \text { to } 0.23)\end{array}$ & 0.100 & $\begin{array}{c}0.11 \\
(0.02 \text { to } 0.2)\end{array}$ & 0.020 \\
\hline Infantilising (end consultation) & $\begin{array}{c}-0.39 \\
(-0.67 \text { to }-0.11)\end{array}$ & 0.009 & $\begin{array}{c}-0.31 \\
(-0.86 \text { to } 0.25)\end{array}$ & 0.044 \\
\hline $\begin{array}{l}\text { Social talk occurred during } \\
\text { whole consultation }\end{array}$ & $\begin{array}{c}0.20 \\
(-0.04 \text { to } 0.44)\end{array}$ & 0.092 & $\begin{array}{c}0.29 \\
(0.4 \text { to } 0.54)\end{array}$ & 0.026 \\
\hline
\end{tabular}

aUnless specified, predictor variables were those rated at the beginning of the consultation. ${ }^{b}$ Univariate analysis ( $n=243$ ) controlled for clustering by doctor. Multivariate analysis ( $n=191)$ controlled for clustering by doctor, deprivation, type of problem, marital status, attitude to doctors, time on the history, and for all significant predictors listed. In this and subsequent tables the estimate of the beta coefficients from the model are quoted; the interpretation of these, taking the first line as the example are that for each gesture used the mean item score for satisfaction increases by 0.11 in univariate analysis and 0.08 in multivariate analysis. MISS = Medical Interview Satisfaction Scale.

\begin{abstract}
Analysis
The data were analysed using SPSS (for data manipulation) and Stata (for modelling) statistical software for Windows ${ }^{\text {TM }}$ using multiple linear regression, controlling for clustering by GP (Stata version 12; SPSS version 21). The linearity of associations was checked graphically and using ordered categorical variables. The dependent
\end{abstract}

\section{Table 2. Variables associated with patient rating of a communication and partnership approach}

\begin{tabular}{|c|c|c|c|c|}
\hline Predictor variables ${ }^{\mathrm{a}}$ & Univariate & $P$-value & Multivariate & $\boldsymbol{P}$-value \\
\hline \multicolumn{5}{|l|}{ Non-verbal } \\
\hline $\begin{array}{l}\text { Number of gestures } \\
\text { (beginning consultation) }\end{array}$ & $\begin{array}{c}0.09 \\
(0.01 \text { to } 0.17)\end{array}$ & 0.030 & $\begin{array}{c}0.09 \\
(0.03 \text { to } 0.16)\end{array}$ & 0.009 \\
\hline $\begin{array}{l}\text { Physical contact occurred } \\
\text { during whole consultation }\end{array}$ & $\begin{array}{c}0.90 \\
(0.15 \text { to } 1.65)\end{array}$ & 0.021 & $\begin{array}{c}1.59 \\
(0.25 \text { to } 2.93)\end{array}$ & 0.022 \\
\hline $\begin{array}{l}\text { Non-verbal cut-off occurred } \\
\text { (end consultation) }\end{array}$ & $\begin{array}{c}-1.92 \\
(-2.64 \text { to }-1.20)\end{array}$ & $<0.001$ & $\begin{array}{c}-1.82 \\
(-2.91 \text { to }-0.72)\end{array}$ & 0.002 \\
\hline $\begin{array}{l}\text { Verbal } \\
\text { Psychosocial talk occurred } \\
\text { in the whole consultation }\end{array}$ & $\begin{array}{c}0.10 \\
(-0.02 \text { to } 0.23)\end{array}$ & 0.100 & $\begin{array}{c}-0.20 \\
(-0.39 \text { to }-0.01)\end{array}$ & 0.040 \\
\hline $\begin{array}{l}\text { Social talk occurred during } \\
\text { whole consultation }\end{array}$ & $\begin{array}{c}0.24 \\
(-0.01 \text { to } 0.49)\end{array}$ & 0.059 & $\begin{array}{c}0.43 \\
(0.14 \text { to } 0.73)\end{array}$ & 0.006 \\
\hline
\end{tabular}

Univariate $(n=239)$ controlling for clustering by doctor. Multivariate $(n=214)$ controlling for clustering by doctor, deprivation, type of problem, attitude to doctors, and for all significant predictors listed. variables were the patients' rating of the consultations and the independent variables were ratings of the physician's behaviour (both verbal and non-verbal), as well as the rest of the data from the questionnaires.

Variables were selected manually by forward selection (to limit the development of spurious findings from automated procedures), and variables retained if there was limited inflation of standard errors, and if they were found to be significant $(P<0.05)$ in multivariate analysis. All variables were then also checked manually in the final model, to ensure no variables that could be important had been overlooked land which could have been spuriously thrown out by an automated procedure). Missing values were not imputed.

\section{RESULTS}

Patients were recruited from February until April each year from 2006 until 2010 by 25 GPs: 9/25 (36\%) female; 6/25 (24\%) not partners; and 5/25 (20\%) working in deprived inner city areas.

Most patients could not be approached because of insufficient time to consent prior to the consultation. Of those who were approached, most agreed to participate $(60 \%)$, with the remainder either not having the time or inclination to participate $(35 \%)$, or because of the sensitive nature of the consultation (5\%).

Of the 360 patients who initially agreed, 275 useable videotapes could be rated, and of these, 251/275 (91\%) have useable questionnaire data, that is, a MISS questionnaire could be calculated.

The mean age of the index patients was 48 years, 138/215 (64\%) were female, $145 / 223$ (65\%) were married, 13/197 (7\%) were in receipt of sickness or disability benefit, 111/228 (49\%) were in paid work, and had on average been to the doctor five times in the previous 12 months.

Patients rated both satisfaction and communication in the consultation highly: the mean item score for MISS on a 1-7 scale was 5.6 (standard deviation [SD] $=0.8$ ), for the communication and partnership scale 5.5 (SD = 0.8), the personal relationship scale 5.1 (SD = 1.3), and the interest in life scale $5.2(S D=1.2)$.

Table 1 shows the results for the MISS questionnaire. Patients' rating of satisfaction (mean item score on the MISS questionnaire, scaled 1-7) increased with slight lean towards the patient, the number of gestures, and back-channel prompts' (such as saying 'mmm', 'ah ha', and so on), at the beginning. Social talk at some point in the consultation was 


\section{Table 3. Variables associated with patient rating of a personal relationship}

\begin{tabular}{lcccc} 
Predictor variables & Univariate & $\boldsymbol{P}$-value & Multivariate & $\boldsymbol{P}$-value \\
\hline $\begin{array}{l}\text { Non-verbal } \\
\begin{array}{l}\text { Non-verbal cut-off occurred } \\
\text { (end consultation) }\end{array}\end{array}$ & $\begin{array}{c}-3.25 \\
(-5.08 \text { to }-1.42)\end{array}$ & 0.001 & $\begin{array}{c}-3.02 \\
(-4.77 \text { to }-1.27)\end{array}$ & 0.002 \\
\hline $\begin{array}{l}\text { Verbal } \\
\text { Social talk occurred during } \\
\text { whole consultation }\end{array}$ & $\begin{array}{c}0.40 \\
(-0.11 \text { to } 0.91)\end{array}$ & 0.115 & $\begin{array}{c}0.49 \\
(0.16 \text { to } 0.83)\end{array}$ & 0.006 \\
\hline $\begin{array}{l}\text { Evidence that patient history not } \\
\text { known during whole consultation }\end{array}$ & $\begin{array}{c}-1.26 \\
(-1.78 \text { to }-0.73)\end{array}$ & $<0.001$ & $\begin{array}{c}-0.70 \\
(-1.23 \text { to }-0.17)\end{array}$ & 0.012 \\
\hline $\begin{array}{l}\text { Overall impression } \\
\text { Optimistic (beginning } \\
\text { consultation) }\end{array}$ & $\begin{array}{c}-0.02 \\
(-0.17 \text { to } 0.14)\end{array}$ & 0.809 & $\begin{array}{c}-0.17 \\
(-0.27 \text { to }-0.06)\end{array}$ & 0.003 \\
\hline $\begin{array}{l}\text { Aloof (end consultation) } \\
-0.40\end{array}$ & 0.001 & $\begin{array}{c}-0.23 \\
(-0.46 \text { to } 0.00)\end{array}$ & 0.05 \\
\hline Dominant (end consultation) & $\begin{array}{c}-0.05 \\
(-0.15 \text { to } 0.04)\end{array}$ & 0.267 & $\begin{array}{c}-0.14 \\
(-0.20 \text { to }-0.07)\end{array}$ & $<0.001$ \\
\hline
\end{tabular}

Univariate ( $n=242)$ controlling for clustering by doctor. Multivariate $(n=213)$ controlling for clustering by doctor, type of problem, attitude to doctors, time on history, and for all significant predictors listed.

associated with increased satisfaction, and infantilising (being patronising) at the end of the consultation was associated with a negative impact.

Tables 2-4 document the associations for the key communication domains. Information on the perception of health promotion, a positive approach, and enablement domains are shown in Appendices 1-3. Variables with estimates

\section{Table 4. Variables associated with patient rating of perceived} interest of the doctor in their life

\begin{tabular}{|c|c|c|c|c|}
\hline Predictor variables & Univariate & $P$-value & Multivariate & $P$-value \\
\hline \multicolumn{5}{|l|}{ Non-verbal } \\
\hline $\begin{array}{l}\text { Non-verbal cut-off occurred } \\
\text { (end consultation) }\end{array}$ & $\begin{array}{c}-1.69 \\
(-2.62 \text { to }-0.76)\end{array}$ & 0.001 & $\begin{array}{c}-2.42 \\
(-4.60 \text { to }-0.25)\end{array}$ & 0.030 \\
\hline \multicolumn{5}{|l|}{ Verbal } \\
\hline $\begin{array}{l}\text { Joke or laugh during the } \\
\text { whole consultation }\end{array}$ & $\begin{array}{c}0.37 \\
(0.01 \text { to } 0.74)\end{array}$ & 0.047 & $\begin{array}{c}0.40 \\
(0.05 \text { to } 0.76)\end{array}$ & 0.027 \\
\hline \multicolumn{5}{|l|}{ Overall impression } \\
\hline Supportive (beginning consultation) & $\begin{array}{c}0.07 \\
(-0.11 \text { to } 0.24)\end{array}$ & 0.451 & $\begin{array}{c}0.29 \\
(0.17 \text { to } 0.41)\end{array}$ & $<0.001$ \\
\hline Optimistic (beginning consultation) & $\begin{array}{c}-0.04 \\
(-0.16 \text { to } 0.09)\end{array}$ & 0.565 & $\begin{array}{c}-0.17 \\
(-0.27 \text { to }-0.06)\end{array}$ & 0.002 \\
\hline Aloof (end consultation) & $\begin{array}{c}-0.14 \\
(-0.28 \text { to }-0.01)\end{array}$ & 0.040 & $\begin{array}{c}-0.30 \\
(-0.59 \text { to }-0.01)\end{array}$ & 0.041 \\
\hline $\begin{array}{l}\text { Aloof (beginning } \\
\text { consultation) }\end{array}$ & $\begin{array}{c}0.17 \\
(0.09 \text { to } 0.26)\end{array}$ & $<0.001$ & $\begin{array}{c}0.33 \\
(0.22 \text { to } 0.44)\end{array}$ & $<0.001$ \\
\hline $\begin{array}{l}\text { Infantilising } \\
\text { (end consultation) }\end{array}$ & $\begin{array}{c}-0.57 \\
(-1.12 \text { to }-0.01)\end{array}$ & 0.046 & $\begin{array}{c}-0.61 \\
(-1.12 \text { to }-0.10)\end{array}$ & 0.020 \\
\hline
\end{tabular}

Univariate ( $n=216$ ) controlling for clustering by doctor. Multivariate $(n=211)$ controlling for clustering by doctor, type of problem, and for all significant predictors listed. that were either significant in both univariate analysis and multivariate analysis, or significant in multivariate analysis but a consistent direction in both univariate and multivariate analysis, are highlighted in Table 5. The pattern of findings in Table 5 suggest being aloof, dominant, or infantilising at the end of the consultation, or using non-verbal cutoffs were associated with several domains of negative perceptions of communication by patients. The negative effect of being aloof or infantilising at the end of the consultation must be put in the context that for only a minority of consultations was there a negative rating: 23/268 (9\%), and $32 / 268$ (12\%), respectively. Being physically engaged lusing gestures or appropriate touch) and socially engaged (social talk) had positive effects. At the beginning of the consultation being supportive was helpful, but optimism was not. Conversely, being professionally aloof at the beginning of the consultation was helpful; suggesting a cool but supportive listening approach, without injecting artificial optimism at too early a stage, could be optimal.

\section{DISCUSSION}

\section{Summary}

This exploratory study is one of the largest to assess a range of verbal and non-verbal behaviours. It suggests that several non-verbal behaviours and nonspecific verbal behaviours, such as social talk and back-channelling, may impact more than traditional verbal behaviours. It also proposes that a changing consultation dynamic may be important - from being professionally supportive but 'cooler' at the beginning to being warmer and avoiding non-verbal cut-offs at the end.

\section{Strengths and limitations}

This was one of the largest studies to assess a very broad range of verbal and non-verbal behaviours in primary care.

The main potential limitations of this study are confounding and type I errors. Type I error is less likely for variables that had multiple associations, and more likely for variables only associated with one outcome and only in multivariate analysis (for example, the rate of speech) or with mixed effects (for example, lean towards the patient and being definite about the nature of the problem). Confounding was controlled as necessary for age, sex of the doctor, type of problem, being in receipt of sickness and unemployment benefit, whether the patient was seeing their usual doctor, and attitudes to doctors. 

Table 5. Summary of significant positive (beneficial outcome) and negative ladverse outcome) associations
of key variables and whether the variable rating refers to the beginning, end, or whole consultation

\begin{tabular}{|c|c|c|c|c|c|c|c|}
\hline Predictor variables & $\begin{array}{l}\text { Satisfaction } \\
\text { (MISS) }\end{array}$ & $\begin{array}{c}\text { Personal } \\
\text { relationship }\end{array}$ & Interest in life & $\begin{array}{c}\text { Health } \\
\text { promotion }\end{array}$ & $\begin{array}{l}\text { Positive } \\
\text { approach }\end{array}$ & $\begin{array}{c}\text { Communication/ } \\
\text { partnership }\end{array}$ & Enable \\
\hline Optimistic (beginning) & & Negative & Negative & & & & \\
\hline Not knowing patient (whole) & & Negative $^{a}$ & & & & & \\
\hline Aloof (end) & & Negative $^{a}$ & Negative $^{a}$ & Negative & Negative & & \\
\hline Dominant (end) & & Negative & Negative & & & & \\
\hline Infantilising (end) & Negative $^{a}$ & & Negative $^{a}$ & Negative & & & \\
\hline Psychosocial talk (whole) & & & & & Negative & Negative & \\
\hline $\begin{array}{l}\text { Mismatch rate/tone } \\
\text { of speech (end) }\end{array}$ & & & & & & & Negative \\
\hline Open questions (end) & & & & & Negative & & \\
\hline Non-verbal cut-off (end) & & Negative $^{a}$ & Negative $^{a}$ & & & Negative $^{a}$ & \\
\hline Supportive (beginning) & & & Positive & & & & \\
\hline Gestures (beginning) & Positive $^{a}$ & & & & & Positive $^{a}$ & \\
\hline Physical contact (whole) & & & & & Positive $^{a}$ & Positive $^{\text {a }}$ & \\
\hline Social talk (whole) & Positive $^{a}$ & Positive $^{a}$ & & & Positive $^{a}$ & Positive $^{a}$ & \\
\hline Joke/laugh (whole) & & & Positive $^{a}$ & & & & \\
\hline $\begin{array}{l}\text { Back-channelling } \\
\text { (beginning) }\end{array}$ & Positive & & & & & & \\
\hline Aloof (beginning) & & & Positive $^{a}$ & & & & \\
\hline Lean (beginning) & Positive & & & & & & Negative \\
\hline Definite about problem & & & & & Positive & & Negative \\
\hline
\end{tabular}

Even with the range of variables controlled for it is difficult to deal with residual confounding, and there is also the danger of over-fitting. However variables, such as non-verbal cut-offs or being aloof or infantilising, which were significant and had similar estimates in both univariate and multivariate analysis (that is, stable estimates and less likely to be confounded), provide stronger evidence of causality.

Conversely, concerns about confounding are stronger when the estimates are unstable, hence variables with more consistent estimates were highlighted. Type II error ( $\beta$ ) is also possible, even though this is one of the largest studies to assess such a complete range of variables (very large studies are challenging due to the very intensive nature of the video assessment). Reverse causality is likely to be relevant for some variables, for example, psychosocial talk (which is likely to occur in consultations with more distress and emotion expressed) was associated with negative perception of communication. Although Rosenthal et al have shown that naïve raters can use their scales reliably, ${ }^{21-23}$ judgements about each item will inevitably be subjective, although the impact of a single rater's judgement was minimised by using several raters. Similarly, despite using the Stewart method which has an extensive manual, ${ }^{2}$ the estimation of reliability in this study suggests that for many variables reliability is only likely to be moderate, and so the associations may have been underestimated. Booking interval was not controlled for but total time in the consultations was not an important predictor.

These results should be confirmed in a wider group of GPs: although patients from GPs working in deprived areas had slightly higher MISS ratings and a 'positive' doctor approach, and partners had higher ratings than non-partners, these variables were controlled for in analysis. Selection bias potentially applies to both doctor and patient: Mead and Bower suggested that doctors who consider themselves to be good communicators, are thus likely to have better verbal communication skills and are more likely to take part, which will have potentially underestimated the importance of verbal skills. ${ }^{24}$ Patients with a sensitive nature to their problem/s are more reluctant to be filmed, and it is in such areas where patient-centredness is likely to be most important. ${ }^{24}$ 
Recruitment and rating of videotapes was slow due to the day-to-day running being coordinated each year by medical students as part of their research projects, and students could only provide concentrated input for 1-2 months per year. The requirement to use students in part reflects the difficulty of obtaining funding for this research. Furthermore, due to the logistic requirement to approach patients and obtain consent, a large proportion of consultations were not recorded.

\section{Comparison with existing literature}

Several variables in the current study were apparently important but only at the end of the consultation. The importance of avoiding non-verbal cut-offs supports Mehrabian, ${ }^{25,26}$ and suggests that non-verbal cut-offs give the patient the impression that the doctors communication skills are poor and that the doctor is not interested in their life. As might be expected, avoiding any sense of distance at the end of the consultation, such as aloof or infantilising/patronising, ${ }^{22,23}$ was powerful, although few doctor consultations in this study were judged to be very aloof or infantilising. The apparently surprising findings of some benefit from being 'aloof' and not overly optimistic at the beginning of the consultation suggests a changing dynamic throughout the consultation. This may reflect the importance early in the consultation of a cooler but supportive professional manner in helping patients feel listened to. The use of gestures and touch, that is, appropriate physical contact, are both supported by previous work, ${ }^{26,27}$ and were consistent between univariate and multivariate analysis.

The use of social conversations was important and is one of the central measures in the Roter interaction analysis system ${ }^{28,29}$ Where there was social conversation, patients were more likely to feel there was a communication and partnership approach, a personal relationship, and that the doctor was positive. Some of this may be reverse causality given that patients who know their doctor better are more likely to be engaged in social conversation and vice versa. However, controlling for whether this was the patient's normal doctor did not modify the estimates, so reverse causality seems a less likely explanation. As expected demonstrating knowledge of the patient and their history was relevant for patients having a sense of a personal relationship, and this finding was also not affected by whether the doctor was the patient's usual doctor. This highlights the importance when the GP is not the usual doctor of quickly checking the key elements of the patient's past history.

Conventional approaches in conceptualising verbal aspects of patientcentredness - exploring the disease, understanding the person as a whole, and finding common ground - were not strong findings. This is closer to Mead and Bower who found very limited associations, ${ }^{24}$ but the correlations in Kinnersley et al's study were also not large. ${ }^{20}$ This may reflect the limited range of GPS - studies of communication tend to enlist those already most interested in communication - but the range of scores for verbal communication perhaps makes this explanation less likely.

\section{Implications for research and practice}

Given the exploratory nature of this study, and the likely self-selection of GPs, very firm recommendations cannot be made. However, if these results can be confirmed, they suggest that health professionals should pay attention to non-verbal skills in the consultation, particularly the use of gestures and physical contact, and to non-specific verbal elements such as backchannel prompts and social conversation. A professionally cool approach may be helpful at the beginning of the consultation, but not at the end where a warmer approach and particular care to avoid non-verbal cut-offs are needed.
Freely submitted; externally peer reviewed.

\section{Competing interests}

The authors have declared no competing interests.

\section{Acknowledgements}

On behalf of the patient communication project team: Marinar Paramour, Anna Jackson, Olayiwola Olatawura, Becky Hawes, Emma Marston, Jennifer Walsh, Hannah Ebdon, Corrina Quinney and Fiona Hignett lall medical students at the time).

\section{Discuss this article}

Contribute and read comments about this article: bjgp.org/letters 


\section{REFERENCES}

1. Stewart MA. Effective physician-patient communication and health outcomes: a review. CMAJ 1995; 152(9): 1423-1433.

2. Brown JB, Stewart M, Tessier S. Assessing communication between patients and doctors: a manual for scoring patient-centred communication. Working Paper Series 95-2. London: Centre for Studies in Family Medicine and Thames Valley Family Practice Research Unit, 1995

3. Barry CA, Bradley CP, Britten N, et al. Patients' unvoiced agendas in general practice consultations: qualitative study. BMJ 2000; 320(7244): 1246-1250.

4. Britten N, Stevenson FA, Barry CA, et al. Misunderstandings in prescribing decisions in general practice: qualitative study. BMJ 2000; 320(7233): 484-488

5. Law SA, Britten N. Factors that influence the patient centredness of a consultation. Br J Gen Pract 1995; 45(399): 520-524.

6. Meryn S. Improving doctor-patient communication. Not an option, but a necessity. BMJ 1998; 316(7149): 1922-1930.

7. Maguire P, Fairbairn S, Fletcher C. Consultation skills of young doctors: Benefits of feedback training in interviewing as students persist. Br Med J (Clin Res Ed) 1986; 292(6535): 1573-1576.

8. Little P, Stuart B, Moore M, et al. Amoxicillin for acute lower-respiratory-tract infection in primary care when pneumonia is not suspected: a 12-country, randomised, placebo-controlled trial. Lancet Infect Dis 2013; 13(2): 123-129.

9. Butler CC, Simpson SA, Dunstan F, et al. Effectiveness of multifaceted educational programme to reduce antibiotic dispensing in primary care: practice based randomised controlled trial. BMJ 2012; DOI: 10.1136/bmj.d8173.

10. Cals JW, de Bock L, Beckers PJ, et al. Enhanced communication skills and C-reactive protein point-of-care testing for respiratory tract infection: 3.5-year follow-up of a cluster randomized trial. Ann Fam Med 2013; 11(2): 157-164.

11. Dwamena F, Holmes-Rovner M, Gaulden CM, et al. Interventions for providers to promote a patient-centred approach in clinical consultations. Cochrane Database Syst Rev 2012; 12;12: CD003267.

12. Beck RS, Daughtridge R, Sloane PD. Physician-patient communication in the primary care office: a systematic review. J Am Board Fam Pract 2002; 15(1): $25-38$

13. Little $\mathrm{P}$, Everitt $\mathrm{H}$, Williamson I, et al. Preferences of patients for patient centred approach to consultation in primary care: observational study. BMJ 2001 322(7284): $468-472$

14. Little $\mathrm{P}$, Everitt $\mathrm{H}$, Williamson I, et al. Obervational study of effect of patient centredness and positive approach on outcomes of general practice consultations. BMJ 2001; 323(7318): 908-911.

15. Griffin SJ, Kinmonth AL, Veltman MW, et al. Effect on health-related outcomes of interventions to alter the interaction between patients and practitioners: systematic review of trials. Ann Fam Med 2004; 2(6): 595-608

16. Hallam D, Doggett $L$, Wilkin MA. Measures of need and outcome for primary health care. Oxford: Oxford University Press, 1992

17. Marteau TM, Bekker H. The development of a six-item short-form of the state scale of the Spielberger State-Trait Anxiety Inventory (STAI). Br J Clin Psychol 1992; 31(3): 301-306.

18. Howie JG, Heaney DJ, Maxwell M, et al. Quality at general practice consultations: cross sectional survey. BMJ 1999; 319(7212): 738-743.

19. Paterson C. Measuring outcomes in primary care: a patient generated measure, MYMOP, compared with the SF-36 health survey. BMJ 1996 312(7037): 1016-1020

20. Kinnersley P, Stott N, Peters TJ, Harvey I. The patient-centredness of consultations and outcome in primary care. Br J Gen Pract 1999; 49(446) $711-716$

21. Ambady N, Laplante $D$, Nguyen $T$, et al. Surgeons' tone of voice: a clue to malpractice history. Surgery 2002; 132(1): 5-9.

22. Ambady N, Koo J, Rosenthal R, Winograd CH. Physical therapists' nonverbal communication predicts geriatric patients' health outcomes. Psychol Aging 2002; 17(3): 443-452

23. Ambady N, Rosenthal R. Thin slices of expressive behavior as predictors of interpersonal consequences: a meta-analysis. Psychological Bulletin 1992; 111(2): 256-274.

24. Mead N, Bower P. Measuring patient-centredness: a comparison of three observation-based instruments. Patient Educ Couns 2000; 39(1): 71-80.

25. Mehrabian A. Nonverbal communication. Chicago, IL: Aldine Atherton Inc., 1972

26. Mehrabian A. Some referents and measures of nonverbal behavior. Behavior Res Meth Instrument 1968; 1: 203-207.

27. Gleeson M, Timmins F. A review of the use and clinical effectiveness of touch as a nursing intervention. Clin Eff Nurs 2005; 9: 69-77.

28. Roter D, Larson S. The Roter interaction analysis system (RIAS): utility and flexibility for analysis of medical interactions. Patient Educ Couns 2002; 46(4): 243-251.

29. Sandvik M, Eide $H$, Lind $M$, et al. Analyzing medical dialogues: strength and weakness of Roter's interaction analysis system (RIAS). Patient Educ Couns 2002; 46(4): 235-241. 


\begin{tabular}{|c|c|c|c|c|}
\hline Predictor variables & Univariate & $P$-value & Multivariate & $P$-value \\
\hline $\begin{array}{l}\text { Non verbal } \\
\text { Non verbal cut-off occurred } \\
\text { (end consultation) }\end{array}$ & $\begin{array}{c}-2.28 \\
(-3.20 \text { to }-1.37)\end{array}$ & $<0.001$ & $\begin{array}{c}-2.89 \\
(-5.35 \text { to }-0.43)\end{array}$ & 0.023 \\
\hline $\begin{array}{l}\text { Object manipulation } \\
\text { (end consultation) }\end{array}$ & $\begin{array}{c}-0.13 \\
(-0.27 \text { to } 0.01)\end{array}$ & 0.074 & $\begin{array}{c}-0.21 \\
(-0.38 \text { to }-0.04)\end{array}$ & 0.020 \\
\hline $\begin{array}{l}\text { Computer use (beginning } \\
\text { and end combined) }\end{array}$ & $\begin{array}{c}-0.34 \\
(-0.70 \text { to } 0.02) \\
\end{array}$ & 0.066 & $\begin{array}{c}-0.59 \\
(-1.02 \text { to }-0.16) \\
\end{array}$ & 0.010 \\
\hline $\begin{array}{l}\text { Verbal } \\
\text { Feedback examination } \\
\text { (findings unsolicited) }\end{array}$ & $\begin{array}{c}0.001 \\
(-0.08 \text { to } 0.08)\end{array}$ & 0.976 & $\begin{array}{c}0.41 \\
(0.13 \text { to } 0.68)\end{array}$ & 0.006 \\
\hline $\begin{array}{l}\text { Overall impression } \\
\text { Aloof (beginning consultation) }\end{array}$ & $\begin{array}{c}0.07 \\
(-0.17 \text { to } 0.31)\end{array}$ & 0.546 & $\begin{array}{c}0.34 \\
(0.21 \text { to } 0.48)\end{array}$ & $<0.001$ \\
\hline Aloof (end consultation) & $\begin{array}{c}-0.04 \\
(-0.36 \text { to } 0.29) \\
\end{array}$ & 0.816 & $\begin{array}{c}-0.28 \\
(-0.49 \text { to }-0.07) \\
\end{array}$ & 0.011 \\
\hline Infantilising (end consultation) & $\begin{array}{c}-0.34 \\
(-0.88 \text { to } 0.20)\end{array}$ & 0.210 & $\begin{array}{c}-0.69 \\
(-1.15 \text { to }-0.23)\end{array}$ & 0.005 \\
\hline
\end{tabular}

Univariate $(n=224)$ controlling for clustering by doctor. Multivariate $(n=195)$ controlling for clustering by doctor, type of problem, history time, total number of medical problems, and for all significant predictors listed.

\begin{tabular}{|c|c|c|c|c|}
\hline Predictor variables & Univariate & $P$-value & Multivariate & $P$-value \\
\hline \multicolumn{5}{|l|}{ Non verbal } \\
\hline $\begin{array}{l}\text { Negative facial expression } \\
\text { (end consultation) }\end{array}$ & $\begin{array}{c}-2.13 \\
(-3.53 \text { to }-0.72) \\
\end{array}$ & 0.005 & $\begin{array}{c}-2.06 \\
(-3.61 \text { to }-0.52)\end{array}$ & 0.011 \\
\hline $\begin{array}{l}\text { Lean towards the patient } \\
\text { (end consultation) }\end{array}$ & $\begin{array}{c}-0.01 \\
(-0.02 \text { to } 0.01)\end{array}$ & 0.002 & $\begin{array}{c}-0.02 \\
(-0.03 \text { to }-0.01)\end{array}$ & 0.006 \\
\hline $\begin{array}{l}\text { Physical contact occurred } \\
\text { during whole consultation }\end{array}$ & $\begin{array}{c}2.39 \\
\text { (0.53 to } 4.23 \text { ) }\end{array}$ & 0.014 & $\begin{array}{c}2.52 \\
(0.03 \text { to } 5.00) \\
\end{array}$ & 0.047 \\
\hline $\begin{array}{l}\text { Negative head movement } \\
\text { (beginning consultation) }\end{array}$ & $\begin{array}{c}1.05 \\
\text { (0.58 to } 1.52)\end{array}$ & $<0.001$ & $\begin{array}{c}1.22 \\
(0.62 \text { to } 1.82)\end{array}$ & $<0.001$ \\
\hline \multicolumn{5}{|l|}{ Verbal } \\
\hline How definite about natural history & $\begin{array}{c}0.12 \\
(-0.01 \text { to } 0.25)\end{array}$ & 0.077 & $\begin{array}{c}0.13 \\
(0.02 \text { to } 0.23)\end{array}$ & 0.021 \\
\hline Social talk during whole consultation & $\begin{array}{c}0.28 \\
(-0.14 \text { to } 0.70)\end{array}$ & 0.177 & $\begin{array}{c}0.62 \\
(0.10 \text { to } 1.13)\end{array}$ & 0.021 \\
\hline $\begin{array}{l}\text { Psychosocial talk during } \\
\text { whole consultation }\end{array}$ & $\begin{array}{c}-0.20 \\
(-0.48 \text { to } 0.07)\end{array}$ & 0.135 & $\begin{array}{c}-0.55 \\
(-0.88 \text { to }-0.22)\end{array}$ & 0.002 \\
\hline Open questions (end consultation) & $\begin{array}{c}-1.23 \\
(-2.69 \text { to } 0.23)\end{array}$ & 0.095 & $\begin{array}{c}-1.35 \\
(-2.65 \text { to }-0.04) \\
\end{array}$ & 0.044 \\
\hline $\begin{array}{l}\text { Overall impression } \\
\text { Aloof (beginning consultation) }\end{array}$ & $\begin{array}{c}0.01 \\
{[-0.28 \text { to } 0.29]}\end{array}$ & 0.968 & $\begin{array}{c}0.17 \\
(0.05 \text { to } 0.29)\end{array}$ & 0.007 \\
\hline Aloof (end consultation) & $\begin{array}{c}-0.18 \\
(-0.64 \text { to } 0.29)\end{array}$ & 0.437 & $\begin{array}{c}-0.34 \\
(-0.64 \text { to }-0.04)\end{array}$ & 0.026 \\
\hline
\end{tabular}

Univariate controlling for clustering by doctor. Multivariate controlling for clustering by doctor, type of problem, deprived practice, state anxiety and for all significant predictors listed. 


\begin{tabular}{|c|c|c|c|c|}
\hline Predictor variables & Univariate & $P$-value & Multivariate & $P$-value \\
\hline $\begin{array}{l}\text { Non verbal } \\
\text { Lean (beginning consultation) }\end{array}$ & $\begin{array}{c}-0.01 \\
(-0.02 \text { to } 0.00)\end{array}$ & 0.041 & $\begin{array}{c}-0.01 \\
(-0.02 \text { to } 0.00)\end{array}$ & 0.045 \\
\hline $\begin{array}{l}\text { Match of rate of speech } \\
\text { (end consultation) }\end{array}$ & $\begin{array}{c}-1.08 \\
(-1.94 \text { to }-0.21)\end{array}$ & 0.017 & $\begin{array}{c}-1.92 \\
(-3.22 \text { to }-0.62)\end{array}$ & 0.006 \\
\hline $\begin{array}{l}\text { Match of patient and doctor tone } \\
\text { (beginning consultation) }\end{array}$ & $\begin{array}{c}-0.19 \\
(-0.53 \text { to } 0.15)\end{array}$ & 0.262 & $\begin{array}{c}-0.35 \\
(-0.52 \text { to } 0.17) \\
\end{array}$ & 0.001 \\
\hline $\begin{array}{l}\text { Verbal } \\
\text { Feedback examination }\end{array}$ & $\begin{array}{c}-0.01 \\
(-0.05 \text { to } 0.02)\end{array}$ & 0.463 & $\begin{array}{c}-0.04 \\
(-0.07 \text { to }-0.01)\end{array}$ & 0.013 \\
\hline Definite about the problem & $\begin{array}{c}-0.03 \\
(-0.06 \text { to }-0.01)\end{array}$ & 0.167 & $\begin{array}{c}-0.05 \\
(-0.09 \text { to }-0.02)\end{array}$ & 0.005 \\
\hline $\begin{array}{l}\text { Overall impression } \\
\text { Hostile (beginning consultation) }\end{array}$ & $\begin{array}{c}-0.62 \\
(-1.00 \text { to }-0.24)\end{array}$ & 0.003 & $\begin{array}{c}-0.39 \\
(-0.59 \text { to }-0.18)\end{array}$ & 0.001 \\
\hline
\end{tabular}

Univariate ( $n=234)$ controlling for clustering by doctor. Multivariate $(n=206)$ controlling for clustering by doctor, type of problem, deprived practice, attitude to doctors and for all significant predictors listed. 